\title{
Evaluation of Fine Needle Aspiration Cytology in the Diagnosis of Lung Lesions
}

\section{Akciğer Lezyonlarının Tanısında İnce İğne Aspirasyon Sitolojisinin Değerlendirilmesi}

\author{
Manas MADAN ${ }^{1}$, Hema BANNUR ${ }^{2}$ \\ Department of Pathology, 'Giansagar Medical College and Hospital, AMRITSAR/PUNJAB, \\ ${ }^{2}$ Jawaharlal nehu Medical College, BELGAUM/KARNATAKA, INDIA
}

\section{ABSTRACT}

Objective: The present study was undertaken to evaluate the diagnostic efficacy of image guided percutaneous fine needle aspiration cytologyFNAC in various lung lesions - both neoplastic and non-neoplastic.

Material and Method: Over a period of one year, computerized tomography (CT)-guided FNAC was performed in forty patients presenting with respiratory symptoms with a localized lung lesion clinically, which was confirmed radiologically.

Results: Male preponderance was noted in this study with M:F ratio of 2.08:1. Malignancy was the predominant lesion found in this study with twenty-four cases (60\%). Among the malignant lesions, adenocarcinoma was the commonest malignancy followed by squamous cell carcinoma. Material in two cases was inadequate for interpretation. Adenocarcinoma was the commonest malignancy seen in females. However, adenocarcinoma was still more common in males overall. Squamous cell carcinoma was the commonest malignancy seen in males. Squamous cell carcinoma was the commonest malignancy among smokers. The diagnostic accuracy was $95 \%$ considering cytological criteria as the standard.

Conclusion: Transthoracic CT-guided FNAC is a relatively safe and accurate procedure in the diagnosis of difficult lung lesions. FNAC should be used earlier and more frequently to shorten the diagnostic interval and allow more prompt therapy for persistent lung lesions.

Key Words: Fine needle aspiration, Cytology, Lung, Adenocarcinoma, Squamous cell carcinoma, Computerized tomography.
ÖZ

Amaç: Bu çalışma hem neoplastik hem de neoplastik olmayan çeşitli akciğer lezyonlarında görüntülüme yöntemi eşliğinde yapılan ince iğne aspirasyon sitolojisinin-İİAS tanısal etkinliğini değerlendirmek için yapılmıştır.

Gereç ve Yöntem: Klinik olarak solunum semptomları ile radyolojik olarak da kanıtlanan akciğer lezyonu bulunan 40 hastaya, bir yıllık bir zaman diliminde bilgisayarlı tomografi-BT eşliğinde İ̇AS uygulandı.

Bulgular: Çalışmada erkek cinsiyet baskınlığ $(\mathrm{E}: \mathrm{K}=2.08: 1)$ belirlendi. En sık görülen lezyon 24 olgu ile (\%60) malignite olarak saptandı. Malign lezyonlar içinde en sik görülen adenokarsinom ve bunu takiben skuamöz hücreli karsinomdu. İki olguda materyaller yorum için yetersizdi. Kadınlarda en sık görülen malignite adenokarsinomdu. Buna karşın adenokarsinom genel olarak yine de erkeklerde daha fazlaydı. Erkeklerde en sık görülen malignite skuamöz hücreli karsinomdu. Skuamöz hücreli karsinom, sigara içenler arasında en sık görülen maligniteydi. Sitolojik kriterler standart olarak kabul edildiğinde tanısal doğruluk oranı $\% 95$ olarak bulundu.

Sonuç: Transtorasik BT eşliğinde yapılan İIAS, zorlayıcı akciğer lezyonlarının tanısında görece güvenilir ve doğru sonuç veren bir yöntemdir. İİAS, persistan akciğer lezyonlarında tanı süresini kısaltmak ve daha hızlı bir tedavi sağlamak için daha erken dönemde ve daha sık olarak kullanılmalıdır.

Anahtar Sözcükler: İnce iğne aspirasyonu, Sitoloji, Akciğer, Adenokarsinom, Skuamöz hücreli karsinom, Bilgisayarlı tomografi.

\section{INTRODUCTION}

Percutaneous fine needle aspiration cytology (FNAC) of the lung is generally indicated for the diagnosis of pulmonary lesions. There are many hazards associated with performing thoracotomy for lung lesions. FNAC has become a diagnostic tool to assess the nature of radiographically demonstrable lung lesions (1-3). The general acceptance of

Received : 30.08.2009

Accepted : 11.11 .2009
FNA has been low but the appreciation of this method for lung lesions has been rapid due to the difficulty in otherwise diagnosing small peripheral lung lesions. Fear of neoplastic implantation in the needle track may have initially inhibited its use but have proven groundless (4). Recognition of the accuracy of FNAC and simpler methods of treating pneumothorax has brought this method within the reach of

Correspondence: Manas MADAN

Department of Pathology, Giansagar Medical College and Hospital, AMRITSAR/PUNJAB, INDIA

E-mail: manasmadan@gmail.com Phone: +911 762507541 
most hospital radiologists and pathologists (5-8). Infections and other benign processes may be proven by this method but the main indication remains the diagnosis of suspected malignant intrathoracic lesions. All intrathoracic lesions including deep hilar lesions are now routinely and safely sampled using FNA under computerized tomography (CT) guidance (9-12). The present study was undertaken to determine the accuracy and efficacy of percutaneous FNAC in the diagnosis of various lung lesions.

\section{MATERIAL and METHODS}

A total of forty cases were included in the study. The study period was from October 2004 to September 2005. All patients presented with respiratory symptoms with a localized lung lesion clinically, which was confirmed radiologically. Patients were placed in the supine, prone, right lateral or left lateral position depending on the location of the lesion so that the lesion was nearest to the aspirator. Lesions were considered peripheral when more than $2 \mathrm{~cm}$ in diameter and within $4 \mathrm{~cm}$ from the skin. Informed consent was obtained from the patient after a brief explanation of the technique. Premedication was generally avoided except in one patient who was old and anxious, where an atropine injection was given prior to FNAC. After aspiration, half of the slides were immediately fixed in 95\% ethanol and Papanicolaou (Pap) stained. The rest were air-dried, later fixed in methanol and stained using the May GrünwaldGiewsa (MGG) stain. The patient was watched carefully for signs of pneumothorax and a follow-up X-ray performed four hours after the FNAC to look for any such signs.

The results were classified into five categories: (1) Inflammatory, (2) Granulomatous lesion/ Tuberculosis, (3) Suspicious of malignancy, (4) Positive for malignancy, (5) Inadequate for interpretation

\section{RESULTS}

The diagnostic accuracy was $95 \%$ considering cytological criteria as the standard. The most common age group affected was $41-70$ years (67.5\%). However age groups in both extremes of life were affected less. The youngest patient was 20 years old whereas the oldest was 78 years old. Of the forty patients, twenty-seven were males and thirteen were females. A male preponderance was therefore noted in this study with a M:F ratio of 2.08:1.

Table I shows the distribution of the cases. The predominant lesion found in this study was malignancy in twenty-four cases $(60 \%)$, followed by an inflammatory lesion in twelve cases (30\%). One case each was reported as suspicious of malignancy (2.5\%) and as a granulomatous lesion (2.5\%) (Figure 1). The material was inadequate for interpretation in two cases (5\%). Out of twenty-four FNAC-proven cases of malignancy, twenty were males $(83.33 \%)$ and only four were females (16.66\%). Hence, there was a significant male preponderance in malignant cases with a M:F ratio of 5:1. Table II shows the cytological typing of malignant lesions. The most common malignant lesion seen was adenocarcinoma in twelve cases (30\%) (Figure 2). Two of these were diagnosed as bronchioloalveolar carcinoma (Figures 3,4). Squamous cell carcinoma was diagnosed in nine cases $(22.5 \%)$ whereas three cases were classified as undifferentiated carcinomas (7.5\%) (Figures 5,6,7).

Table I: Distribution of cases

\begin{tabular}{|l|c|c|}
\hline \multicolumn{1}{|c|}{ Diagnosis } & Number & $\begin{array}{c}\text { Percentage } \\
\text { (\%) }\end{array}$ \\
\hline Inflammatory & 12 & 30 \\
\hline Granulomatous & 1 & 2.5 \\
\hline Suspicious of malignancy & 1 & 2.5 \\
\hline Positive for malignancy & 24 & 60 \\
\hline Inadequate for interpretation & 2 & 05 \\
\hline Total & 40 & 100 \\
\hline
\end{tabular}

Table II: Cytological typing of malignant lesions

\begin{tabular}{|l|c|c|}
\hline \multicolumn{1}{|c|}{ Typing } & Number & $\begin{array}{c}\text { Percentage } \\
\text { (\%) }\end{array}$ \\
\hline Adenocarcinoma: & 12 & 30 \\
\hline • Conventional & 10 & 25 \\
\hline • Bronchioloalveolar & 2 & 5 \\
\hline Squamous cell carcinoma & 9 & 22.5 \\
\hline Undifferentiated carcinoma & 3 & 7.5 \\
\hline Total & 24 & 60 \\
\hline
\end{tabular}

Adenocarcinoma was the commonest malignancy seen in females. Three out of four females positive for malignancy were diagnosed as adenocarcinoma. However, adenocarcinoma was still more common in males overall with a M:F ratio of 2.3:1. Squamous cell carcinoma was the commonest malignancy seen in males with a M:F ratio of 3.5:1.

Table III shows the association with smoking. Sixteen out of forty patients were smokers. All of them were males. Thirteen out of sixteen smokers were positive for malignancy $(81.25 \%)$. Squamous cell carcinoma was 
diagnosed in seven of these thirteen patients and five were diagnosed as adenocarcinoma, of which one was diagnosed as bronchioloalveolar carcinoma. There was therefore a strong predisposition to develop lung carcinoma among smokers and squamous cell carcinoma was the commonest malignancy among smokers. No major complications were encountered in this study, however one patient developed

Table III: Association with smoking

\begin{tabular}{|l|c|c|}
\hline \multicolumn{1}{|c|}{ History of smoking } & Number & $\begin{array}{c}\text { Percentage } \\
\text { (\%) }\end{array}$ \\
\hline Present & 16 & 40 \\
\hline Absent & 24 & 60 \\
\hline Total & 40 & 100 \\
\hline
\end{tabular}

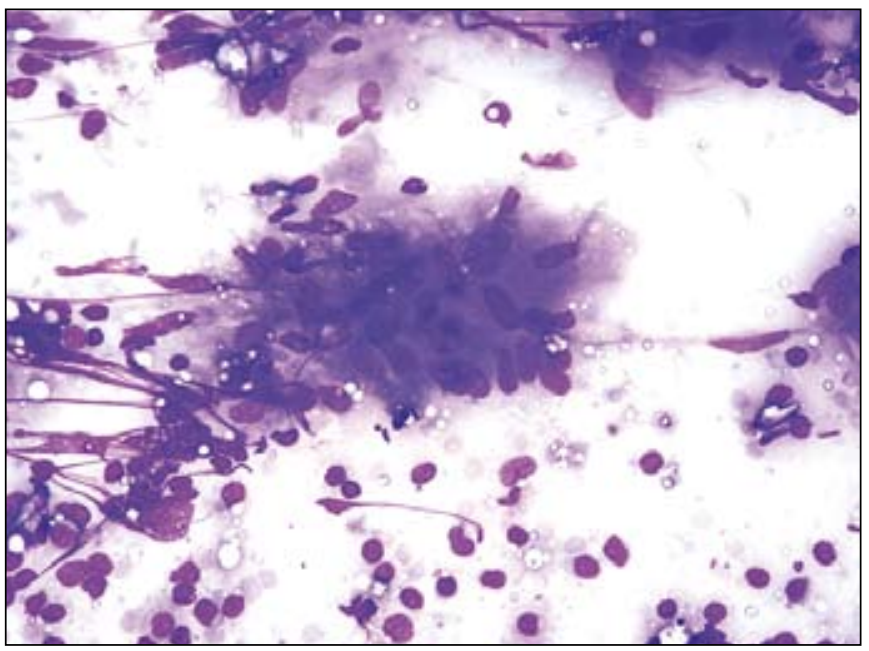

Figure 1: Granulomatous lesion - A cluster of epitheloid cells and few lymphocytes (MGG, $\mathrm{x} 400$ ).

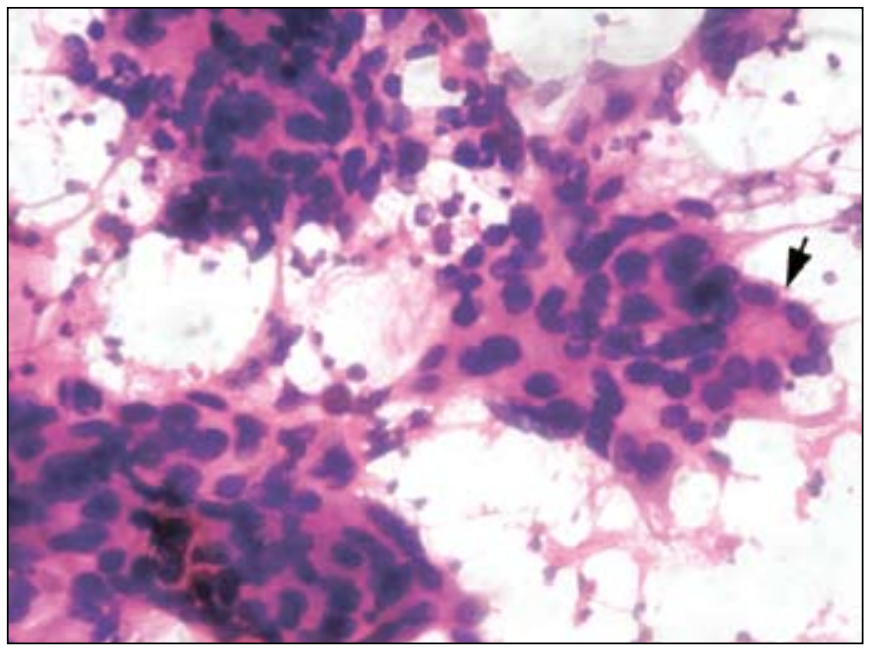

Figure 2: Adenocarcinoma - Neoplastic cells with delicate cytoplasm and pleomorphic, hyperchromatic nucleus arranged in cell clusters and glandular pattern (arrow) (Pap, x400). dyspnoea following FNAC. He was treated successfully with an adrenaline injection (Figure 1-7).

\section{DISCUSSION}

Fine needle aspiration of intrathoracic organs is generally applied to localized lesions, its use being limited in the diagnosis of diffuse parenchymal disease. Proof of malignancy is the usual aim of such a procedure although it can be used for definitive diagnosis of some benign neoplasms and infections such as tuberculosis (13-15).

Different imaging modalities such as fluoroscopy, ultrasonography, and computed tomography have been used by various authors $(1,4,7,13,16-18)$. Computed tomography is widely used nowadays $(16,17,19,20)$.

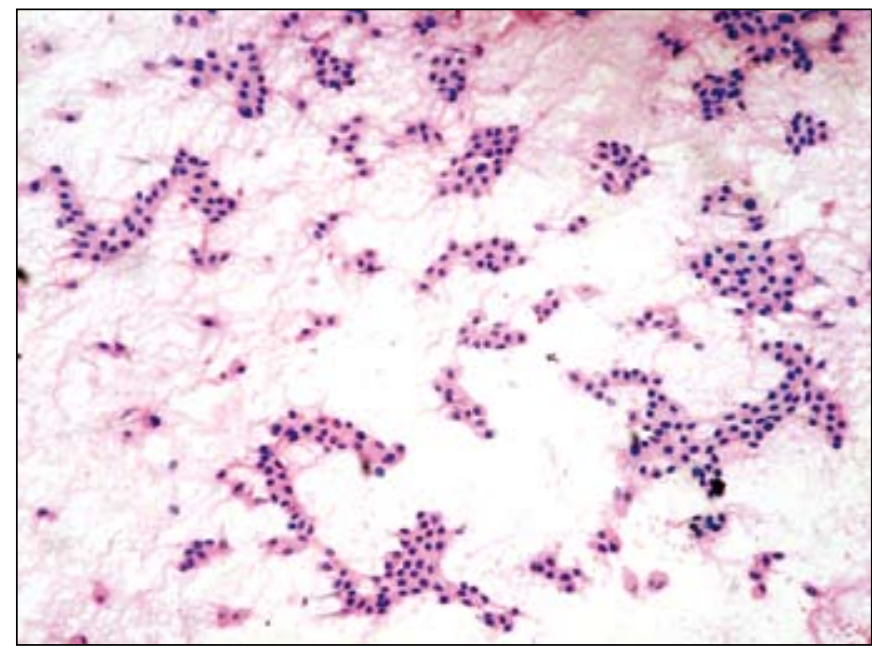

Figure 3: Bronchioloalveolar carcinoma - Mildly pleomorphic cells arranged in cohesive sheets (Pap, x100).

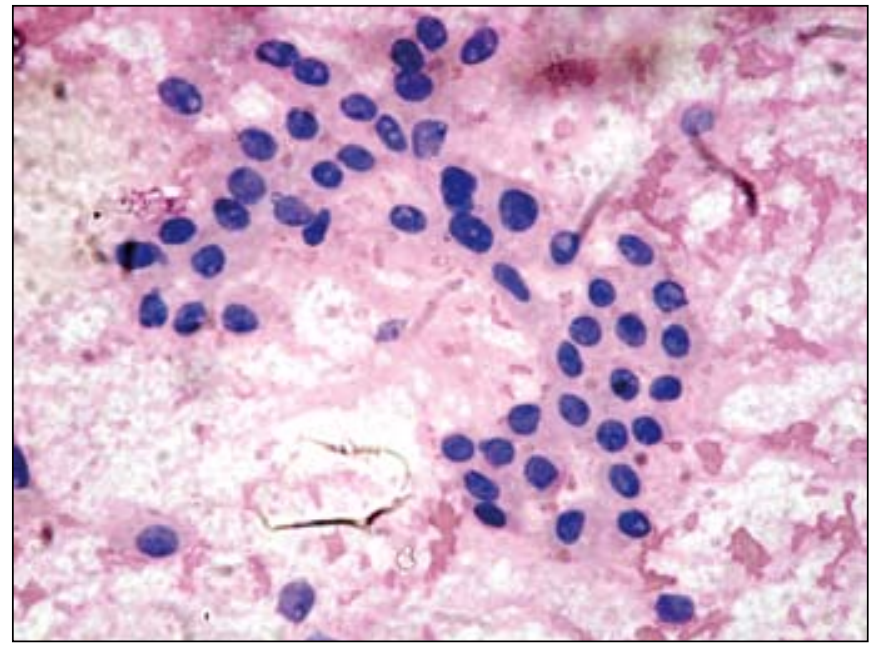

Figure 4: High power of the above tumor showing prominent intranuclear vacuoles (Pap, x400). 


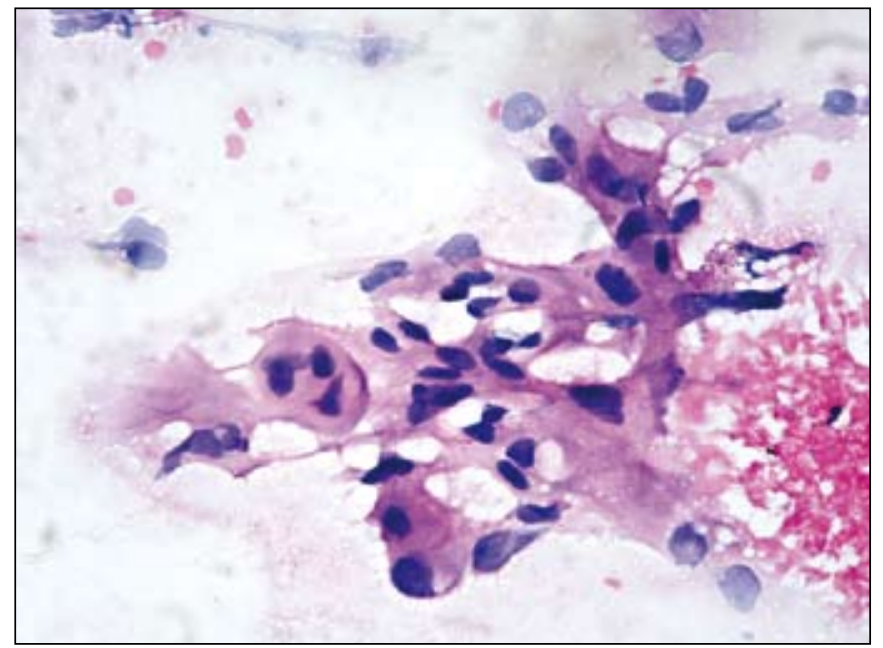

Figure 5: Squamous cell carcinoma - A cluster of neoplastic squamous cells with highly pleomorphic cells having ample eosinophilic cytoplasm (Pap, x400).

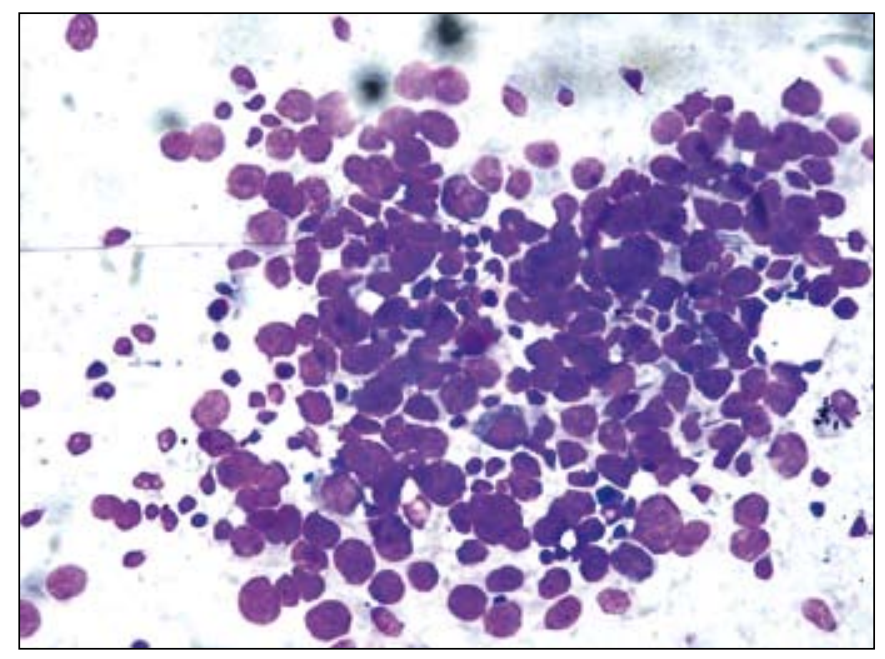

Figure 6: Undifferentiated carcinoma - Highly pleomorphic, undifferentiated cells in sheets (MGG, x400).

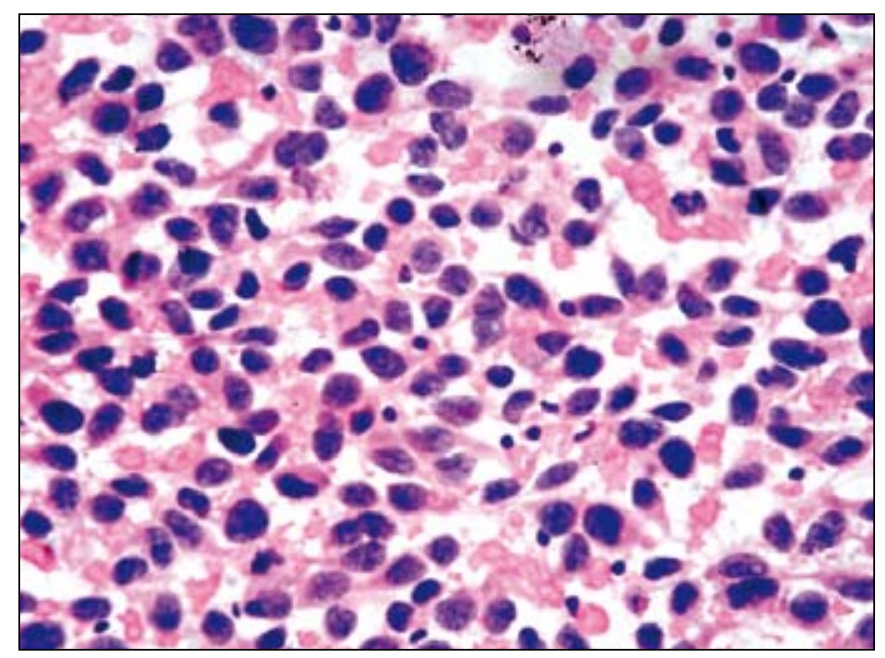

Figure 7: Undifferentiated carcinoma - Highly pleomorphic, undifferentiated cells in sheets (Pap, x400).
The present study consisted of forty-three aspirations performed on forty patients. In three cases (7.5\%), repeat aspiration helped to obtain adequate material as the material was inadequate in the first instance. The aspiration was repeated in these cases as there was a strong suspicion of malignancy on clinical and radiological examination. Different studies cite a repeat aspiration rate of $13 \%$ for an inconclusive first aspiration. It is also stated that an unsatisfactory aspiration must be repeated, particularly when there is strong suspicion of possible malignancy (13).

In two cases (5\%), the material was inadequate for interpretation but aspiration could not be repeated either because the patient was uncooperative or lost to follow up. Various studies have shown the rate of inadequate sampling to vary from $8.8 \%$ to $25.4 \%(1-3,6,7)$. The reasons quoted are faulty technique, necrosis, tumor location and patient compliance (4).

There was a male preponderance in the present study with a M:F ratio of 2.08:1. The ratio in lung lesions as quoted by various authors ranges from $1.7: 1$ to $2.6: 1$. This difference is explained on the basis of higher incidence of predisposing factors like smoking, COPD and alcoholism in males $(21,22)$. Among FNAC-proven cases of malignancy, twenty were males $(83.33 \%)$ and only four were females (16.66\%). There was therefore a significant male preponderance with a M:F ratio of 5:1.

Twenty-four cases were positive for malignancy $(60 \%)$ in the present study. The features were suspicious of malignancy but FNAC could not be repeated as the patient was lost for follow up in one case (2.5\%). Repeated aspirations helped to obtain a specific diagnosis later in three cases. Various studies cite the incidence of malignant tumors on lung FNAC as $58-88 \%$. The above findings correlated with the observations made by various authors $(9,21,23,24)$.

Adenocarcinoma was the commonest tumor in females. Three of four females were diagnosed as adenocarcinoma. However it was still more common in males overall with a M:F ratio of 2.3:1. Squamous cell carcinoma was the commonest tumor in males with a M:F ratio of 3.5:1.

Cancer of the lung is a disease of middle and late periods. The incidence is low in those below 35 years, rises to a peak at about 60 years and declines slowly thereafter. In the present study, sixteen patients were smokers (40\%) and all of them were males. Thirteen of 16 were positive for malignancy (81.25\%). Among the smokers, squamous cell carcinoma was the commonest malignancy with seven cases $(53.8 \%)$ followed by adenocarcinoma with 5 five 
cases (38.46\%). These findings correlated with the results of previous authors. The relationship with smoking is strongest for squamous cell carcinoma $(21,22)$.

Twelve of our cases were diagnosed as adenocarcinoma (30\%) that included two cases of bronchioloalveolar carcinoma closely followed by squamous cell carcinoma in nine cases $(22.5 \%)$. Though squamous cell carcinoma used to be considered the commonest tumor of the lung, studies indicate that adenocarcinoma may have overtaken it in incidence $(21,22)$.

Bronchioloalveolar carcinoma constituted two cases in the present study (5\%). One of these patients was a smoker. BAC represents $1-9 \%$ of all lung cancers in various series. It is less frequently associated with a history of smoking than are squamous cell carcinomas. More than $75 \%$ of these are still found in smokers (22).

Between $20-30 \%$ of lung carcinomas are adenocarcinomas and the proportion has risen in the last fifteen years. Adenocarcinoma is the most common histological type in women and the rising proportion of women in the lung cancer population is undoubtedly a factor in the relative increase in the incidence of adenocarcinoma $(9,21)$.

Three cases were diagnosed as undifferentiated carcinoma in the present study (7.5\%). Undifferentiated carcinoma constitutes $7-15 \%$ of lung cancers. As no immunocytochemical studies were done in the present study, the above three cases were diagnosed as undifferentiated carcinoma and no further typing could be done (21). Complications were encountered in only one case $(2.5 \%)$, which developed dyspnoea following FNAC. No fatalities were reported in the present study. However major complications have been reported by previous workers, the commonest complication being pneumothorax $(5,6,9,10,18,23,24)$.

Other carcinomas of the lung i.e. small cell carcinoma, giant cell carcinoma and adenosquamous carcinoma were not found in this study. The possible explanation can be the relative rarity of these neoplasms. Small cell carcinoma accounts for $10-20 \%$ whereas both giant cell carcinoma and adenosquamous carcinoma make up less than $5 \%$ of lung malignancies. The site of occurrence of small cell carcinoma is further a hindrance to its diagnosis by FNAC. It occurs predominantly in the central portions of the lung, in the major bronchi $(21,22)$.

\section{CONCLUSION}

Percutaneous, transthoracic FNAC is a relatively simple procedure with good patient acceptance and low morbidity.
It is an accurate, safe and repeatable procedure in the diagnosis of difficult lung lesions. CT scan has enabled the visualization of previously inaccessible tumors, which can now be guided by this procedure, leading to a greater yield of cytological material and a significantly greater predictability of true positive cases in malignant lesions. FNAC should be used earlier and more frequently to shorten the diagnostic interval and allow more prompt therapy for persistent lung lesions.

\section{REFERENCES}

1. Iwasaki A, Kamihara Y, Yoneda S, Kawahara K, Shirakusa T: Video-assisted thoracic needle aspiration cytology for malignancy of the peripheral lung. Thorac Cardiovasc Surg 2003, 51: 89-92

2. Kim HK, Shin BK, Cho SJ, Moon JS, Kim MK, Kim CY, Park SH, Kim KT, In KH, Oh YH, Kang EY, Park SH, Kim I: Transthoracic fine needle aspiration and core biopsy of pulmonary lesions. A study of 296 patients. Acta Cytol 2002, 46: 1061-1067

3. Gullón JA, Fernández R, Medina A, Rubinos G, Suárez I, Ramos C, González IJ: Transbronchial needle aspiration in bronchogenic carcinoma with visible lesions: diagnostic yield and cost. Arch Bronconeumol 2003, 39: 496-500

4. Orell SR, Sterett GF, Walters MN-I, Whitaker D: Manual and Atlas of Fine Needle Aspiration Cytology, $3^{\text {rd }}$ ed. Edinburgh, Churchill Livingstone, 1999

5. Traill ZC, Gleeson FV: Delayed pneumothorax after CT-guided percutaneous fine needle aspiration lung biopsy. Thorax 1997, 52: 575-576

6. Byrd RP Jr, Fields-Ossorio C, Roy TM: Delayed chest radiographs and the diagnosis of pneumothorax following CT-guided fine needle aspiration of pulmonary lesions. Respir Med 1999, 93: 379-381

7. Santambrogio L, Nosotti M, Bellaviti N, Pavoni G, Radice F, Caputo V: CT-guided fine-needle aspiration cytology of solitary pulmonary nodules: a prospective, randomized study of immediate cytologic evaluation. Chest 1997, 112: 423-425

8. Westcott JL, Rao N, Colley DP: Transthoracic needle biopsy of small pulmonary nodules. Radiology 1997, 202: 97-103

9. Arslan S, Yilmaz A, Bayramgürler B, Uzman O, Unver E, Akkaya $E$ : CT-guided transthoracic fine needle aspiration of pulmonary lesions: accuracy and complications in 294 patients. Med Sci Monit 2002, 8: 493-497

10. Kushwaha SK, Sachan AS, Gupta A, Gupta R, Sharma RD: Efficacy and safety of unguided percutaneous fine needle aspiration cytology in peripheral lung lesions. J Indian Med Assoc 1996, 94: 105-107

11. Larscheid RC, Thorpe PE, Scott WJ: Percutaneous transthoracic needle aspiration biopsy: a comprehensive review of its current role in the diagnosis and treatment of lung tumors. Chest 1998, 114: 704-709

12. Huq MH, Talukder SI, Haque MA, Sarker CB, Saleh AF, Debnath CR: Role of fine needle aspiration cytology in the diagnosis of pulmonary lesions. Mymensingh Med J 2004, 13: 16-19

13. Kline TS: Handbook of Fine Needle Aspiration Biopsy Cytology, $2^{\text {nd }}$ ed. New York, Churchill Livingstone, 1988

14. Das DK, Pant CS, Pant JN, Sodhani P: Transthoracic (percutaneous) fine needle aspiration cytology of pulmonary tuberculosis. Tuber Lung Dis 1995, 76: 84-89 
15. Tan KB, Thamboo TP, Wang SC, Nilsson B, Rajwanshi A, SaltoTellez M: Audit of transthoracic fine needle aspiration of the lung: Cytological subclassification of bronchogenic carcinomas and diagnosis of tuberculosis. Singapore Med J 2002, 43: 570-575

16. Gouliamos AD, Giannopoulos DH, Panagi GM, Fletoridis NK, Deligeorgi-Politi HA, Vlahos LJ: Computed tomography-guided fine needle aspiration of peripheral lung opacities. An Initial Diagnostic Procedure? Acta Cytol 2000, 44: 344-348

17. Kowalewski J, Sir J, Dancewicz M, Swiniarska J, Pepliński J: Fine needle aspiration biopsy under CT-guidance-usefulness in diagnosis of malignant lung tumors. Pneumonol Alergol Pol 2004, 72: 177-180

18. Li H, Boiselle PM, Shepard JO, Trotman-Dickenson B, McLoud TC: Diagnostic accuracy and safety of CT-guided percutaneous needle aspiration biopsy of the lung: comparison of small and large pulmonary nodules. AJR Am J Roentgenol 1996,167: 105109

19. Sheikh M, Sawhney S, Dey P, al-Saeed O, Behbehani A: Deepseated thoracic and abdominal masses: usefulness of ultrasound and computed tomography guidance in fine needle aspiration cytology diagnosis. Australas Radiol 2000, 44: 155-160
20. Garpestad E, Goldberg SN, Herth F, Garland R, LoCicero J 3rd, Thurer R, Ernst A: CT Fluoroscopy guidance for transbronchial needle aspiration: an experience in 35 patients. Chest 2001, 119: 329-332

21. Damjanov I, Linder J: Anderson's Pathology Vol I, $10^{\text {th }}$ Ed. St. Louis, Mosby, 1996

22. Kumar V, Abbas AK, Fausto N: Robins and Cotrans Pathologic Basis of Disease. $7^{\text {th }}$ ed. Philadelphia, Saunders, 2004

23. Mondal A, Pradhan MC: Role of percutaneous fine needle aspiration cytology (FNAC) in detection of lung, pleural and mediastinal tumors - A study of 162 cases. Indian J Pathol Microbiol 1991, 34: 253-258

24. Rajwanshi A, Jayaram N, Behra D, Gupta SK, Malik SK: Fine needle aspiration cytology of intrathoracic lesions - A repraisal. Indian J Pathol Microbiol 1989, 32: 306-309 